\title{
Przesłanie obrazów sportowych zawartych w Listach św. Pawła
}

\author{
Paweł Wańczyk \\ Uniwersytet Papieski Jana Pawła II w Krakowie \\ paw-wan@wp.pl (D) https://orcid.org/0000-0001-5441-1372
}

Zmagania sportowe pełnią ważną rolę w życiu współczesnych ludzi. Igrzyska, mistrzostwa czy nawet pojedyncze mecze cieszą się dużym zainteresowaniem publiczności i stanowią jedną z najpopularniejszych form rozrywki. Podobne wydarzenia absorbowały starożytnych, zwłaszcza zamieszkujących obszary znajdujące się pod wpływem kultury hellenistycznej. Nic więc dziwnego, że także św. Paweł oraz osoby z jego otoczenia chętnie wykorzystywały obrazy sportowe, aby poprzez ukazanie podobieństw z agonistykąa uwypuklić pewne aspekty życia chrześcijańskiego.

Dotychczasowe opracowania omawiające Pawłowe nawiązania do sportu podejmowały analizę tylko większych i ważniejszych perykop lub koncentrowały się na przybliżeniu znaczenia sportu w kontekście życia społecznego i kultury antycznego świata ${ }^{2}$. Niniejszy artykuł ma na celu przyjrzenie się większej ilości fragmentów z Corpus Paulinum oraz wydobycie z nich treści, jakie poprzez takie metafory miały zostać przekazane adresatom. Autor tego opracowania ma nadzieję, że w ten sposób uda się poszerzyć wiedzę na temat badanego zagadnienia.

Analizując metafory sportowe pojawiające się w Corpus Paulinum, można zauważyć pewien rozwój tematyczny. W pierwszych Listach św. Pawła ${ }^{3}$ mają

1 Termin agonistyka oznacza współzawodnictwo w tzw. agonach, czyli zawodach, igrzyskach (sportowych lub artystycznych), odbywających się w starożytnej Grecji ku czci jakiegoś boga lub herosa. Por. Wielki słownik wyrazów obcych PWN, red. M. Bańko, Warszawa 2005, s. 21.

2 Wyjątek stanowi monografia: A. Rambiert-Kwaśniewska, „Walcz $w$ dobrych zawodach o wiarę” (1 Tm 6, 12a). Relektura metaforyki sportowej w listach proto- i deuteropawłowych, Wrocław 2015 (Bibliotheca Biblica), która stanowi najobszerniejsze opracowanie tematyki sportowej w Listach św. Pawła. Niniejszy artykuł powstał przed wydaniem tej monografii, więc wyniki badań w niej opublikowane nie zostały tu uwzględnione.

3 Wprowadzony podział nie jest tożsamy z rozróżnieniem na Listy proto- i deuteropawłowe. W niniejszym artykule zostanie przyjęte tradycyjne rozumienie autorstwa Listów św. Pawła. Nie będzie zatem podejmowana kwestia rzeczywistego pochodzenia tych pism od Apostoła Pawła, 
one głównie na celu ukazanie nawracania ludzi przez Apostoła jako walki sportowej. W późniejszych Listach Pawłowych obrazy ze świata sportu mają już charakter bardziej uniwersalny i służą do opisania życia chrześcijan. Te dwa etapy rozwoju będą stanowić strukturę niniejszego artykułu.

\section{Ewangelizacja jako zmaganie sportowe}

Na początek należy wspomnieć, iż niekiedy Apostoł łączy ze sobą obrazy sportowe i militarne, co utrudnia rozpoznanie tematyki zastosowanych aluzji. Jednak takie powiązanie tych dwóch rzeczywistości niewątpliwie ma swoje źródło w tym, iż w starożytnej Grecji wychowanie agonistyczne i przygotowanie wojskowe były ze sobą ściśle powiązane ${ }^{4}$. Warto również zauważyć, iż niektóre obrazy sportowe przywołane przez św. Pawła odnoszą się do sportu w ogólności, natomiast inne do konkretnych dyscyplin sportowych. Posiadana przez niego dość duża wiedza dotycząca tematyki z zakresu agonistyki, świadczy o tym, iż nie przeszkadzał mu zbytnio fakt, że ówczesne zawody odbywały się ku czci pogańskich bóstw. Co więcej, jak twierdzą niektórzy badacze, mógł on wykorzystywać zgromadzenia publiczne związane $\mathrm{z}$ agonami w celach ewangelizacyjnych - tak mogło być w trakcie jego pobytu w Koryncie, który zbiegł się w czasie z terminem igrzysk w pobliskiej Istmii (51 rok po Chrystusie) ${ }^{5}$.

Pierwszym pismem Pawła, w którym można znaleźć nawiązania o tematyce sportowej, jest 1 List do Tesaloniczan ${ }^{6}$. Został on napisany właśnie w Koryncie, kilka lub kilkanaście miesięcy po założeniu przez Pawła wspólnoty w Tesalonikach i wyraża jego wielką troskę o ten młody Kościół. Apostoł wspominając swoje przybycie do tego miasta, pisze między innymi następujące słowa:

gdyż to zagadnienie jest cały czas dyskutowane, a jednocześnie nie ma większego znaczenia dla tematu podjętego $\mathrm{w}$ artykule.

4 Z tego także względu wynika pewne pokrewieństwo terminologii stosowanej w obu tych dziedzinach. Por. M. F. Baslez, Antyczne chrześcijaństwo wobec kultury sportowej świata grecko-rzymskiego, „Communio. Międzynarodowy Przegląd Teologiczny” 26 (2006) nr 4, s. 5.

5 Por. O. Broneer, The Apostle Paul and the Isthmian Games, „The Biblical Archaeologist” 25 (1962) nr 1, s. 20, https://doi.org/10.2307/3211017.

6 Celem artykułu jest ukazanie przesłania metafor sportowych, a nie przedstawienie rozwoju tego zagadnienia. Z tego to powodu przyjęta chronologia Listów Pawłowych ma jedynie na celu systematyzację prezentowanego materiału biblijnego. 
Sami bowiem wiecie, bracia, że nasze przyjście do was nie okazało się daremne. Chociaż ucierpieliśmy i - jak wiecie doznaliśmy zniewagi w Filippi, odważyliśmy się w Bogu naszym głosić

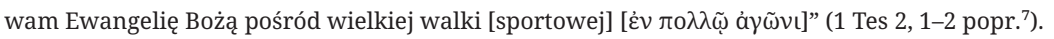

Paweł wskazuje tu okoliczności, w jakich przyszło mu prowadzić dzieło ewangelizacji i ilustruje je sportowym obrazem. Głoszenie Dobrej Nowiny

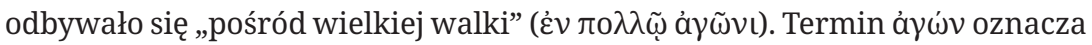
„zgromadzenie, miejsce igrzysk, zawodów”, a także „walkę, sprawę sądową, czy też walkę wewnętrzną, wzburzenie i strach”8. Mimo wielu znaczeń słowo to kojarzyło się szczególnie ze sportem. Ukazana tutaj ewangelizacja napotykała na bardzo wielkie ( $\pi 0 \lambda u ́ s)$ przeszkody, których pokonywanie jest przedstawione jako zmagania sportowe. Tymi trudnościami mogły być wspomniane w wersie 1 wrogość i cierpienia fizyczne, których Paweł i jego współpracownicy doświadczyli w pobliskim Filippi ${ }^{9}$. Nie da się jednak wykluczyć, iż zgodnie z dalszymi znaczeniami terminu á $\gamma \omega \dot{\omega} v$ Apostoł mógł również mieć na myśli jakieś wewnętrzne rozterki czy wręcz strach spowodowany powstałymi rozruchami wśród tłumu i gwałtownym odrzuceniem jego misji. Właśnie w kontekście tych możliwych obaw i lęku łatwiej zrozumieć słowa: „odważyliśmy się w Bogu naszym głosić wam Ewangelię Bożą”. Jednak niezależnie od tego, czy tymi zmaganiami, które musiał stoczyć Apostoł, była wrogość niektórych ludzi, czy też przeszkody wewnętrzne, jak wahania lub przerażenie, kontynuował on swoje posłannictwo. Mówiąc zatem językiem sportu, mimo doświadczanego kryzysu nie poddał się, motywowany czekającą go nagrodą. Zapewne z tego też względu kilkanaście wersetów dalej Paweł, chcąc pokazać adresatom, jak są mu drodzy, podejmuje temat nagrody:

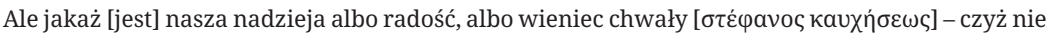
wy również przed Panem naszym, Jezusem Chrystusem, w chwili Jego przyjścia? Wy bowiem jesteście naszą chwałą i radością (1 Tes 2, 19-20) ${ }^{10}$.

7 Przytoczone cytaty pochodzą z Biblii Tysiąclecia (wyd. V), jednakże w sytuacjach, gdy ten przekład nie oddaje sportowego charakteru wypowiedzi zapisanej w języku oryginalnym, wówczas podawane będzie tłumaczenie poprawione przez autora artykułu, a ten fakt oznaczony będzie skrótem popr.

8 Por. Słownik grecko-polski, pod red. Z. Abramowiczówny, t. 1: A- , Warszawa 1958, s. 22.

9 Podobnej nieprzychylności doświadczyli również w Tesalonikach, z których także musieli uchodzić (por. Dz 17, 1-10). Jednakże Paweł nie wspomina o tym, aby nie robić przykrości adresatom.

10 W bardzo podobny sposób św. Paweł zwraca się również do Filipian, rozpoczynając końcowe pouczenia skierowanego do nich Listu od słów: „Przeto, bracia umiłowani i utęsknieni - radości 
Obok innych określeń Tesaloniczanie są nazwani „wieńcem chwały”

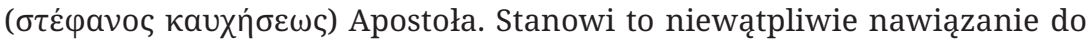
nagrody, jaką otrzymywali sportowcy za zwycięstwo w zawodach. Jednak to nie sam wieniec był główną nagrodą, lecz prestiż i poczucie osiągniętego sukcesu. Nic więc dziwnego, że na zadane przez siebie pytanie od razu odpowiada: „Wy bowiem jesteście naszą chwałą i radością”. Pewną zagadkę stanowi czas odebrania tej nagrody. W pierwszej części pytania brakuje formy czasownika „być” (zdanie nominalne). Zatem ten fragment można również tłumaczyć czasem przyszłym: „jakaż [będzie] nasza nadzieja ...”, co doskonale współbrzmi z drugą częścią pytania, w której jest mowa o „chwili

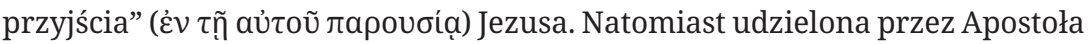
odpowiedź stosuje czas teraźniejszy: „Wy bowiem jesteście naszą chwałą i radością”. Można zatem powiedzieć, że przezwyciężenie przeciwności, na które napotyka ewangelizacja już tu na ziemi, stanowiło dla Pawła powód do dumy i radości. Jednocześnie pozyskanie uczniów dla Chrystusa jest zadatkiem, który pozwoli uzyskać pełnię nagrody, którą będzie zbawienie uzyskane zarówno przez ewangelizującego, jak i ewangelizowanych ${ }^{11}$.

Kolejnym pismem, w którym św. Paweł wykorzystuje tematykę sportową dla opisania swojej działalności misyjnej jest List do Galatów. Apostoł porusza w nim zagadnienie zbawienia otrzymanego jako darmowa łaska, a nie jako skutek wypełniania Prawa Mojżeszowego ${ }^{12}$. Podjęcie takiego tematu wynika z faktu, że w tamtejszej wspólnocie pojawili się fałszywi głosiciele, tzw. judaizujący, którzy nauczali o konieczności wypełniania przez chrześcijan Prawa Mojżeszowego i jednocześnie podważali autorytet Pawła i głoszonej przez niego Ewangelii. W takim to kontekście Apostoł pisze:

Potem [...] udałem się ponownie do Jerozolimy. [...] I przedstawiłem im Ewangelię, którą głoszę wśród pogan, osobno zaś tym, którzy cieszą się poważaniem, [by stwierdzili], czy nie biegnę

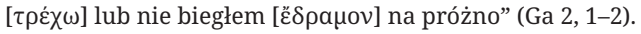

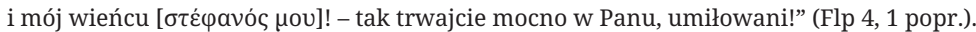

11 Por. M. Bednarz, 1-2 List do Tesaloniczan, Częstochowa 2007, s. 142n. 216-221 (Nowy Komentarz Biblijny. Nowy Testament, 13).

12 Podobną myśl św. Paweł podejmuje także w Liście do Rzymian, stosując kolejne odniesienie do

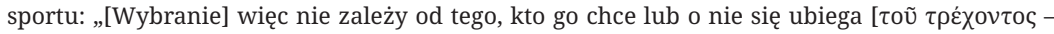
dosł. „od biegnącego”], ale od Boga, który wyświadcza łaskę” (Rz 9, 16). 
W przeciwieństwie do poprzednio omówionych tekstów pojawia się tu konkretna dyscyplina sportowa, a mianowicie biegi. Właśnie do nich Paweł porównuje swoją działalność misyjną, którą poddał weryfikacji apostołów, tak jak biegacz poddaje się ocenie sędziów. „Ewangelizacyjny bieg” św. Pawła byłby bezsensowny i nieprzepisowy, gdyby jego nauczanie zostało uznane za niezgodne z nauką bezpośrednich uczniów Chrystusa. Oznaczałoby to również, że wszystkie założone przez niego wspólnoty nie są w łączności z Kościołem apostolskim. Są to jednak tylko spekulacje, gdyż należy zauważyć, iż Paweł był pewny prawowierności swojego głoszenia (por. Ga 1, 8), a wspomnianej ocenie poddał się ze względu na ewangelizowanych, aby mieli oni pewność prawdziwości głoszonej im Ewangelii. Właśnie dzięki temu, że działalność Pawła zyskała potwierdzenie ze strony wspólnoty jerozolimskiej, został ukazany błąd, w jakim znajdowali się przeciwnicy Pawła, i to zarówno w odniesieniu do osoby Apostoła, jak i głoszonych przez nich fałszywych treści. Jednak ich działalność znalazła przynajmniej częściowy posłuch wśród członków wspólnoty, czego wyrazem jest kolejne pouczenie Pawła występujące w omawianym liście:

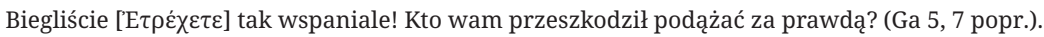

Jest to pierwsze zasygnalizowanie rozwijanego szerzej w późniejszych Listach Pawła obrazu życia chrześcijańskiego jako biegu. Trudno powiedzieć, czy ten zarzut oznacza, że Galaci już zaczęli żyć według fałszywej Ewangelii, czy też Apostoł widział realne niebezpieczeństwo, iż wkrótce to nastąpi. Niezależnie od tych przypuszczeń chce on powiedzieć, że ich życie wiedzione zgodnie z prawdziwą nauką Ewangelii jest niczym dobry, szybki bieg, a przyjęcie fałszywych pouczeń okazałoby się jej porzuceniem i oznaczałoby porażkę ${ }^{13}$.

Następny sportowy obraz można odnaleźć w 1 Liście do Koryntian, w zakończeniu fragmentu, w którym św. Paweł opisuje wewnętrzną wolność, jaka towarzyszy mu w jego misji ewangelizacyjnej ${ }^{14}$. Apostoł Narodów podkreśla tu

13 Por. P. Kasiłowski, Metafory sportowe w Listach Pawta, [w:] Salezjanie a sport, pod red. Z. Dziubińskiego, Warszawa 1998, s. 35-37.

14 Niektórzy badacze odczytują obraz sportowy z 1 Kor 9, 24-27 w jeszcze szerszym kontekście tego Listu i odnoszą go do problemu jedzenia potraw poświęconych bożkom. Jednak takie powiązanie nie jest wcale rzeczą pewną. Por. D. Moreau, „Biegnijcie, aby zwyciężyć”. Bieg wytrzymałościowy a życie chrześcijańskie, „Communio. Międzynarodowy Przegląd Teologiczny” 26 (2006) nr 4, s. 25. 
zarazem, że jakkolwiek okoliczności zewnętrzne głoszenia mogą być różne, to jednak on potrafi się dostosować, a wszystko po to, aby wypełnić powierzone mu zadanie krzewienia Dobrej Nowiny (por. 1 Kor 9, 1-23). W związku z powyższym, aby lepiej wyjaśnić adresatom, czym podyktowana jest konieczność życia zgodnego z Ewangelią, Apostoł pisze:

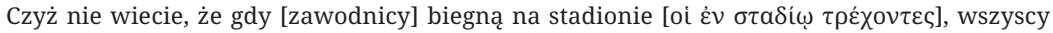

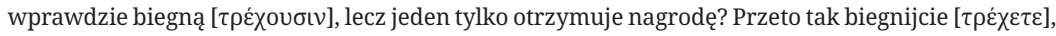
abyście ją otrzymali. Każdy walczący w zawodach [sportowych] [ó ả $\gamma \omega \nu \iota \zeta o ́ \mu \varepsilon v o \varsigma]$ wszystkiego

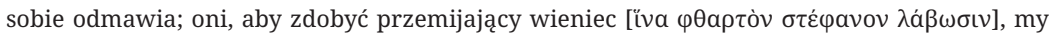

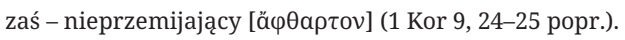

Na początku św. Paweł poprzez pytanie retoryczne odwołuje się do oczywistej zasady, iż tylko jeden zawodnik wygrywa bieg. Wzmianka o jednym wygrywającym nie sugeruje, że tylko jeden konkretny chrześcijanin może zdobyć nagrodę ${ }^{15}$ (życia wiecznego), lecz wskazuje, że każdy uczeń Chrystusa powinien dążyć do tego, aby być najlepszym pod względem dążenia do świętości. Jak kontynuuje Apostoł, zdobycie nagrody zarówno przez sportowca, jak i przez wierzącego, wymaga wyrzeczeń, ale zasadnicza różnica jest w jakości nagrody - zawodnicy walczą o „przemijający wieniec, my zaś - nieprzemijający”. Pisząc do Koryntian o przemijającym wieńcu, Apostoł najprawdopodobniej odwołuje się do igrzysk ismijskich, które odbywały się niedaleko tego miasta. Co ciekawe, w tamtejszych zawodach zwycięzców nagradzano wieńcami uplecionymi z gałązek sosny pinii lub liści selera, a więc były to trofea bardzo nietrwałe, szybko bowiem więdły i zasychały, pozostawiając po sobie garść zeschłych szczątków ${ }^{16}$. W ten sposób Apostoł uwidacznia wielką różnicę jakościową: sportowcy bardzo się trudzą, a ich nagrodą jest coś, co zaświadcza o przemijaniu. Natomiast na chrześcijan czeka wieniec niezniszczalny, którym oczywiście jest zbawienie i życie wieczne z Bogiem. W związku z tym o ileż bardziej uczniowie Jezusa powinni starać się osiągnąć tę nagrodę!

Natomiast w dwóch kolejnych wersetach tej sportowej metafory Apostoł, podając siebie za przykład, mówi:

15 Potwierdzenie tego, że Paweł nie ma na myśli ograniczenia ilości zwycięzców do jednego, stanowi dany przez niego zbiorowy nakaz - „biegnijcie, abyście ją zdobyli” - a przecież w biegu indywidualnym (w starożytności nie uprawiano sztafet) nie może być zwycięzcy kolektywnego. Por. O. Broneer, The Apostle Paul and the Isthmian Games, dz. cyt., s. 16-17. 


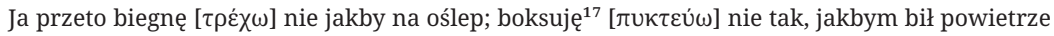

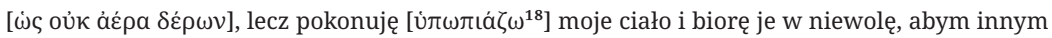
głosząc naukę, sam przypadkiem nie został uznany za niezdatnego” (1 Kor 9, $26-27$ popr.).

W obrazach biegu na oślep (czyli nie do mety) i zadawania ciosów w próżnię egzegeci dostrzegają opis treningu sportowego. Oznaczałoby to, że Paweł chce podkreślić, iż nie traktuje swojej działalności jako ćwiczeń przygotowawczych, lecz jako prawdziwą walkę. Możliwe jest jednak, że poprzez te dwa obrazy chce on również wymownie zaznaczyć, że jego działalność nie jest zmaganiem nieprzemyślanym - musi być skuteczna, tak jak precyzyjne powinny być ciosy boksera i jak konieczne dla biegacza jest trzymanie się wyznaczonej trasy, aby najszybciej dotrzeć do mety ${ }^{19}$. Sposobem osiągnięcia takiej roztropności jest samodyscyplina ukazana tutaj jako poskramianie i branie w niewolę własnego ciała. Ta asceza pomaga Pawłowi żyć Ewangelią, którą głosi, i sprawia, że jest on jej wiarygodnym świadkiem ${ }^{20}$.

Podobne połączenie obrazu sportowca-głosiciela wraz z zachętą, aby adresaci podjęli „zawody trwania przy Ewangelii” można odnaleźć w Liście do Filipian:

Tylko sprawujcie się w sposób godny Ewangelii Chrystusowej, abym ja - czy to gdy przybędę i ujrzę was, czy też będąc z daleka - mógł usłyszeć o was, że trwacie mocno w jednym duchu,

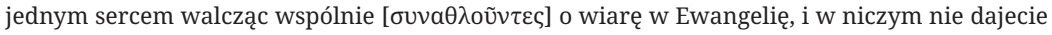
się zastraszyć przeciwnikom. [...] Wam bowiem z łaski dane jest dla Chrystusa: nie tylko w Niego

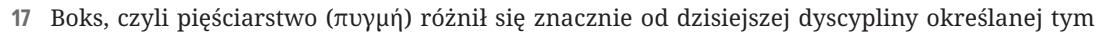
mianem. Ciosy można było zadawać tylko w głowę i ramiona, nie można było przytrzymywać przeciwnika, natomiast można go było bić nawet wówczas, gdy ten leżał. Pięści obwiązywano rzemieniami i przymocowywano niekiedy do nich drobne kamienie, tak by zwiększyć skuteczność uderzeń. Walka nie miała określonego czasu, więc bito się do rozstrzygnięcia. Starożytny boks był zatem bardzo brutalną i krwawą konkurencją. Por. A. Rambiert, Bieg Pawła z Tarsu, czyli spotkania z grecką agonistyka, Wrocław 2013, s. 75-77 (Archeolog Czyta Biblię).

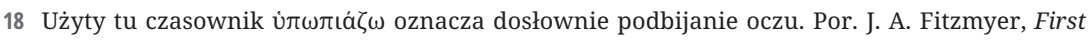
Corinthians. A New Translation with Introduction and Commentary, New Haven-London 2008, s. 374 (The Anchor Yale Bible, 32). Jest to zapewne nawiązanie do brutalności, jaką cechowało się antyczne pięściarstwo.

19 Por. J. P. Urbański, Język metafor i dyscyplin sportowych w Tradycji Pawłowej, „Bielsko-Żywieckie Studia Teologiczne" 5 (2004), s. 269n.

20 Por. G. D. Fee, The First Epistle to the Corinthians, Grand Rapids 1988, s. 437-439 (The New International Commentary on the New Testament). 


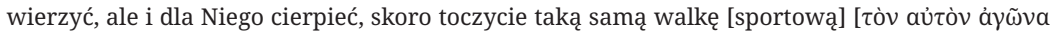

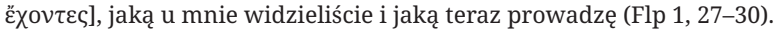

Jak widać, kontekstem, do którego odnosi się ten fragment, jest znów głoszenie fałszywych nauk przez przeciwników Pawła, przy czym niniejszy List nie mówi wprost, czego one dotyczyły. Stały się one jednak sytuacją próby, którą adresaci są w stanie przetrwać o ile zachowają jedność wspólnoty (jeden duch, jedno serce). Ta jedność może być osiągnięta przez wspólny wysiłek zilustrowany tutaj obrazem zespołowej walki sportowej ${ }^{21} \mathrm{o}$ wiarę (w. 27). Takie zmaganie o trwanie przy Ewangelii wymaga wysiłku i łączy się z cierpieniem (w. 29), podobnie jak to ma miejsce w sporcie. Na szczęście tym, co może Filipianom pomóc w ich trudnej sytuacji, jest wzór, jaki mają do naśladowania, a jest nim osoba Pawła (w. 30). Używa on względem siebie obrazu sportowca, ale można jednocześnie powiedzieć, że jest on dla adresatów trenerem i chce, aby „jego zespół” był dla niego powodem do chluby: „Trzymajcie się mocno Słowa Życia, abym mógł być dumny w dniu Chrystusa,

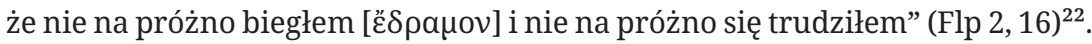

W trzecim rozdziale tego Listu znajduje się kolejny fragment przywołujący obraz sportowy:

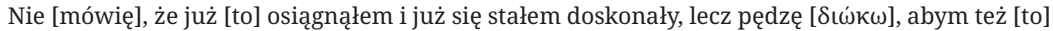
zdobył, bo i sam zostałem zdobyty przez Chrystusa Jezusa. Bracia, ja nie sądzę o sobie samym, że już zdobyłem, ale to jedno [czynię]: zapominając o tym, co za mną, a wytężając siły ku temu,

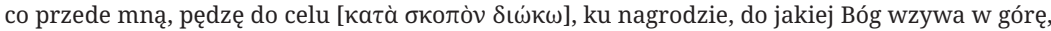
w Chrystusie Jezusie (Flp 3, 12n popr.).

Dla pełniejszego poznania przesłania niniejszego fragmentu ważną rzeczą jest zrozumienie jego pierwszego zdania. Brzmi ono dosłownie: „Nie, że już zdobyłem”. Jak widać, brakuje w nim dopełnienia mówiącego, czym jest to, czego Paweł nie zdobył. Najprawdopodobniej chodzi tu o pełne poznanie

21 Czasownik à $\theta \lambda \dot{\varepsilon} \omega$ oznacza walkę sportową lub militarną, natomiast przedrostek ouv- należy tłumaczyć jako „wspólnie” czy też „razem”. Por. J. Flis, List do Filipian, Częstochowa 2011, s. 185 (Nowy Komentarz Biblijny. Nowy Testament, 11). Podobną ideę współdziałania na rzecz rozszerzania Ewangelii można znaleźć w poleceniach końcowych tego Listu, gdzie Paweł prosi Syzyga o wsparcie Ewodii i Syntychy: „Także proszę i ciebie, prawdziwy Syzygu, pomagaj im, bo one

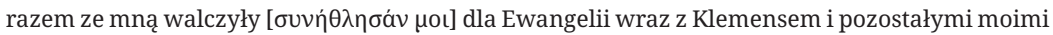
współpracownikami, których imiona są w księdze życia” (Flp 4, 3 popr.).

22 Por. G. F. Hawthorne, Philippians, Grand Rapids 2004, s. 70-72 (Word Biblical Commentary, 43). 
Jezusa Chrystusa, o którym Apostoł pisze w poprzednich wersetach ${ }^{23}$. Jednak ta znajomość Chrystusa raczej nie oznacza intelektualnego poznania, lecz pełnię relacji osobowej Pawła ze swoim Mistrzem. Ponadto, jak wskazuje tekst, Apostołowi brakuje również pełnej doskonałości moralnej. Co ciekawe, biorąc pod uwagę autobiograficzny kontekst przytoczonej wypowiedzi, można sądzić, iż Paweł, pisząc o swojej niedoskonałości, nawiązuje do historii swojego życia, gdy przed laty jako faryzeusz sądził, że wypełnianie przepisów Prawa Mojżeszowego doprowadzi go do doskonałości. Jednak w wydarzeniu pod Damaszkiem Paweł został zdobyty przez Jezusa Chrystusa (w. 12) i teraz wie, że osiągnięcie owej pełni polega właśnie na całkowitym zjednoczeniu się z Nim. Taka pełna bliskość nie jest wynikiem jednorazowego aktu woli, lecz wymaga nieustannego wysiłku. W tym miejscu Apostoł po raz kolejny wykorzystuje obraz sportowy, przedstawiając siebie jako biegacza ${ }^{24}$ zapomi- $^{-}$ nającego o tym, co zostało za nim, a koncentrującego się na tym, co jest przed nim. Mówiąc o zapominaniu tego, co minęło, Paweł może mieć na myśli swoją faryzejską przeszłość wraz z prześladowaniem chrześcijan, ale też swoje późniejsze „ponawróceniowe” ewangelizacyjne osiągnięcia. Oczywiście nie chodzi mu tutaj o wyrzucenie swojej przeszłości z pamięci, lecz o wskazanie pewnej względności zarówno swojego niewłaściwego postępowania, jak też tego, co mogłoby uchodzić za zasługę. To pierwsze nie stanowi przeszkody niemożliwej do pokonania, a drugie z kolei nie daje dostatecznej gwarancji tego, aby osiągnąć ostateczną bliskość z Bogiem. Koncentrowanie się na rzeczach minionych nie ma sensu, tak jak absurdalna jest sytuacja, gdy biegacz wciąż ogląda się za siebie. Dlatego Paweł pisze o wytężaniu wszystkich sił ku celowi. Trudno jednoznacznie powiedzieć, czy w ukazanym obrazie tym celem

23 Podobną tematykę dążenia do coraz większej doskonałości i głębszego poznania Chrystusa Paweł porusza również w Liście do Kolosan, stosując kolejne nawiązania sportowe: „Jego to [Chrystusa] głosimy, upominając każdego człowieka i ucząc każdego człowieka z całą mądrością, aby każdego człowieka przedstawić jako doskonałego w Chrystusie. Po to właśnie się trudzę, walcząc

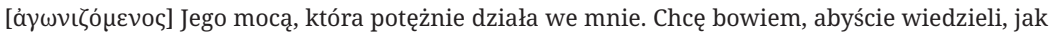
wielką walkę (ảy $\omega v a)$ toczę o was, o tych, którzy są w Laodycei, i o tych wszystkich, którzy nie widzieli mnie osobiście” (Kol 1, 28-2, 1). Po raz kolejny pojawia się tu przyrównanie misji ewangelizacyjnej do zmagań sportowych, jednak co ciekawe, w tym fragmencie Apostoł podkreśla, że zależy mu także na tych chrześcijanach, którzy uwierzyli w Chrystusa na skutek działalności jego współpracowników i nie znają go osobiście.

24 Paweł używa tu dwukrotnie czasownika $\delta \iota \omega ́ \kappa \omega$, który oznacza „pędzić, gnać”, a więc niekoniecznie musi to być obraz biegu i dlatego niektórzy komentatorzy, będący jednak w mniejszości, dostrzegają tu obraz wyścigu rydwanów. Por. J. P. Urbański, Język metafor i dyscyplin sportowych..., dz. cyt., s. 273n. 
(бКото́ৎ) jest meta (jak to interpretuje Biblia Tysiąclecia), czy może zajęcie najwyższego miejsca na podium, jednakże osiągnięcie jednego i drugiego łączy się z otrzymaniem nagrody. Do odebrania tej nagrody wzywa „w górę” (w. 14) Bóg, który jest niczym sędzia wywołujący zwycięzcę do wejścia na podium. Należy jednocześnie zauważyć, że w tym obrazie „wzywania w górę” wybrzmiewa też biblijna myśl o Bogu powołującym człowieka do przebywania z Nim w niebie. Zatem Apostoł w omawianym fragmencie zwraca uwagę, że nie można się zadowolić obecną relacją z Bogiem, z Chrystusem, lecz należy cały czas starać się ją pogłębić tak, aby na koniec biegu-życia otrzymać nagrodę, jaką będzie niebiańska pełnia Boskiej bliskości ${ }^{25}$.

Ciekawy aspekt użycia obrazu sportowego w kontekście ewangelizacji pojawia się również w końcowych fragmentach Listu do Rzymian i Listu do Kolosan:

Proszę więc was, bracia, przez Pana naszego, Jezusa Chrystusa, i przez miłość Ducha, abyście

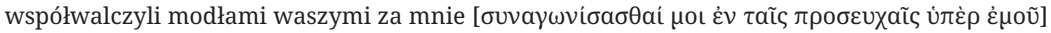
do Boga” (Rz 15, 30 popr.).

Pozdrawia was rodak wasz, Epafras, sługa Chrystusa Jezusa, zawsze walczący o was w modli-

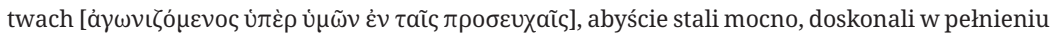
każdej woli Bożej (Kol 4, 12).

Jak widać w pierwszym cytacie, Paweł prosi adresatów o modlitwę w jego intencji, natomiast drugi fragment stanowi zapewnienie, że Epafras, współpracownik Pawła, nieustannie modlitewnie troszczy się o chrześcijan znajdujących się w Kolosach. Wspólnym mianownikiem dla obu wersetów jest przedstawienie modlitwy jako walki sportowej. Modlitwa jako walka duchowa wymaga wysiłku, tak jak zmagania sportowe. Co więcej, w obu rzeczywistościach - modlitwy i sportu - do osiągnięcia sukcesu bardzo potrzebna jest wytrwałość i umiejętność niepoddawania się.

Widzimy zatem, że ewangelizacyjna misja św. Pawła w znacznej mierze wyjaśniana jest adresatom jego Listów za pomocą porównywania jej do zawodów sportowych. Jednak już w omawianych fragmentach pojawiło się rozszerzenie porównań z zakresu agonistyki na kwestię zgodności życia uczniów Chrystusa z głoszoną im Dobrą Nowiną. Takie zestawienie życia

25 Por. G. W. Hansen, The Letter to the Philippians, Grand Rapids-Nottingham 2009, s. $249-257$ (The Pillar New Testament Commentary). 
chrześcijańskiego ze sportem występuje dość często w późniejszych Listach Apostoła Narodów i będzie przedmiotem naszych dalszych rozważań.

\section{2. Życie chrześcijanina jako uczestnictwo w zawodach sportowych}

Pouczenie dotyczące życia chrześcijańskiego wraz z subtelnym nawiązaniem sportowym pojawia się pod koniec Listu do Efezjan, gdzie Paweł, chcąc zachęcić adresatów do oparcia się na Chrystusie, przytacza obraz tzw. zbroi duchowej:

Na koniec bądźcie mocni w Panu - siłą Jego potęgi. Przyobleczcie pełną zbroję Bożą, byście mogli

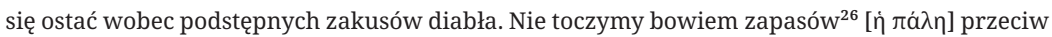
krwi i ciału, lecz przeciw Zwierzchnościom, przeciw Władzom, przeciw rządcom świata tych ciemności, przeciw duchowym pierwiastkom zła na wyżynach niebieskich” (Ef 6, 10-12 popr.).

Chociaż przytoczone wersety oraz ich rozwinięcie (Ef 6, 13-17) przywołują obraz militarny, to jednak mówiąc o samej walce Apostoł używa terminu rá $\lambda \eta$ (,zapasy” $)^{27}$. Dzieje się tak być może dlatego, że chce on uniknąć ukazania życia uczniów Chrystusa jako wojny, co kontrastowałoby z kilkukrotnie akcentowanym w tym liście zagadnieniem pokoju (Ef 2, 14-15; 4, 3; 6, 15). Natomiast, mimo że chrześcijanie są powołani do życia w harmonii z Bogiem i ludźmi, muszą jednak toczyć ciągle walkę z atakującymi ich złymi duchami, określonymi tutaj jako Zwierzchności, Władze, rządcy świata ciemności, duchowe pierwiastki zła na wyżynach niebieskich. Takie zapasy mogą być długotrwałe i bardzo wyczerpujące, a biorąc pod uwagę to, że szatan jest istotą o wyższej

26 Ówczesne zapasy ( $\pi a ́ \lambda \eta$ ) miały inne reguły niż współczesna wersja tej dyscypliny. Walczono na stojąco, natomiast do powalenia przeciwnika można było stosować chwyty obejmujące całe ciało rywala (np. podcinanie nóg). Zwycięstwo polegało na trzykrotnym doprowadzeniu do sytuacji, gdy przeciwnik dotknął ziemi udem, ramieniem lub plecami (a zatem nie wymagane było położenie rywala na łopatki, tak jak to ma miejsce obecnie). Por. A. Rambiert, Bieg Pawła z Tarsu..., dz. cyt., s. 71n.

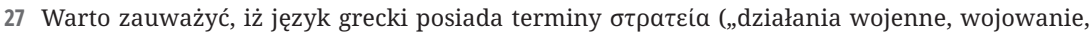

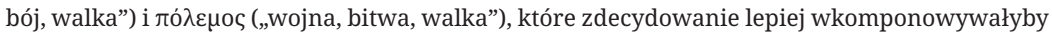
się w obraz przygotowania wojownika do działań zbrojnych. Por. R. Popowski, Wielki słownik grecko-polski Nowego Testamentu, Warszawa 1994, s. 511, 566 (Prymasowska Seria Biblijna, 3). Przy czym trzeba jednocześnie przyznać, iż Apostoł nie przykłada tutaj dużej uwagi do spójności

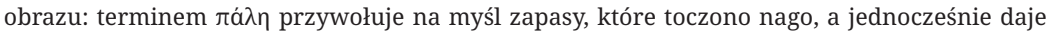
polecenie przywdziania zbroi żołnierskiej. 
inteligencji niż ludzka, człowiek polegający jedynie na własnych siłach nie jest w stanie z nim wygrać. Dlatego chrześcijanie muszą walczyć siłą Bożej potęgi oraz polegać na duchowej zbroi, czyli na prawdzie, sprawiedliwości, gotowości głoszenia dobrej nowiny o pokoju, wierze i zbawieniu, jak też korzystać z broni służącej do duchowej walki - ze słowa Bożego oraz modlitwy (por. Ef 6, 14-18) ${ }^{28}$.

Kolejne sportowe obrazy dotyczące życia ucznia Jezusa można odnaleźć w 1 Liście do Tymoteusza, a jak wskazuje nazwa tego nowotestamentowego pisma, tym razem są one skierowane do konkretnej osoby - Tymoteusza współpracownika Pawła i jednocześnie biskupa Efezu. W tym mieście pojawili się fałszywi głosiciele, najprawdopodobniej gnostycy, którzy między innymi zakazywali zawierania małżeństw oraz spożywania niektórych pokarmów (por. $1 \mathrm{Tm}$ 4, 3). Właśnie te nieprawdziwe nauki Apostoł nazywa bezbożnymi mitami i w tym kontekście wprowadza obraz z zakresu gimnastyki:

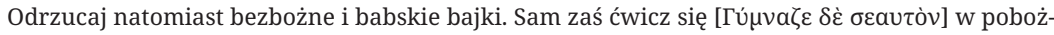

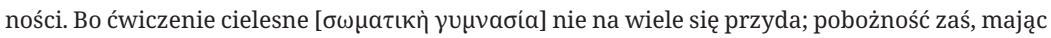
obietnicę życia obecnego i tego, które ma nadejść, przydatna jest do wszystkiego. Nauka to godna

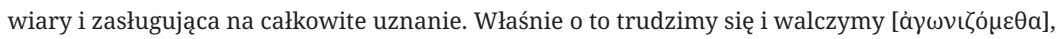
ponieważ złożyliśmy nadzieję w Bogu żywym, który jest Zbawicielem wszystkich ludzi, a zwłaszcza wierzących (1 Tm 4, 7-10 popr.).

Wspomniane tutaj ćwiczenia fizyczne odnoszą się do powstrzymywania się od współżycia małżeńskiego oraz od niektórych posiłków, czyli od rzeczy, które same w sobie są dobre, ponieważ zostały stworzone przez Boga i są powodem do okazywania Mu wdzięczności (por. 1 Tm 4, 4). Jednak w przytoczonym fragmencie Paweł nie akcentuje już nieprawdziwości fałszywych twierdzeń, natomiast podkreśla, że te ascetyczne nakazy nie dają dużej korzyści - są działaniem wyłącznie ludzkim, a ich skutki odnoszą się jedynie do ziemskiego życia. Dlatego Apostoł wspomnianym ćwiczeniom fizycznym przeciwstawia doskonalenie się w pobożności, której owocem będzie bliskość Boga, doświadczana zarówno w doczesnym, jak i przyszłym życiu (w. 8). Tak więc Paweł zaleca Tymoteuszowi ćwiczenie się w pobożności. Właśnie o nią

28 Por. M. Barth, Ephesians. Translation and Commentary on Chapters 4-6, Garden City 1984, s. 763n (The Anchor Bible, 34A). 
oraz o szerzenie prawdziwej nauki (w. 9) powinien on się starać niczym sportowiec walczący w zawodach (w. 10) ${ }^{29}$.

W rozdziale 6 omawianego pisma Paweł ponownie powraca do tematu fałszywych głosicieli, przy czym wskazuje, że ich rzeczywistą motywacją nie jest dążenie do prawdy, lecz chęć zysku. Taka właśnie chęć bogacenia się za wszelką cenę jest powodem popadania w pokusy i pożądania, a nawet wręcz źródłem wszelkiego zła (por. 1 Tm 6, 3-10). W tym kontekście Apostoł udziela Tymoteuszowi następujących pouczeń:

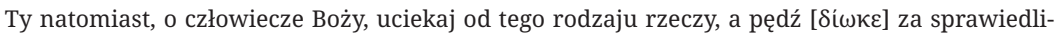
wością, pobożnością, wiarą, miłością, wytrwałością, łagodnością. Walcz w dobrych zawodach,

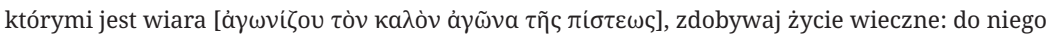
zostałeś powołany i [o nim] złożyłeś dobre wyznanie wobec wielu świadków (1 Tm 6,11n popr.).

Zatem, jak widać, Paweł zbytniemu staraniu się o dobra materialne przeciwstawia cnoty, które powinny cechować dobrego chrześcijanina. Celem biegu Tymoteusza ma być sprawiedliwość, pobożność, miłość, wytrwałość, łagodność, a także wiara (lub też ufność, uczciwość czy wierność, bo również

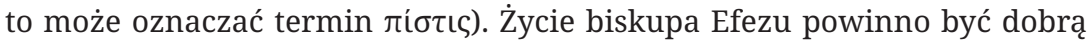
sportową walką. Jednak pewną trudność niesie interpretacja wyrażenia ả $\gamma \omega ́ v$ $\tau$ п̃ऽ $\pi i ́ \sigma \tau \varepsilon \omega \varsigma$, które można rozumieć zgodnie z Biblią Tysiąclecia jako „zawody

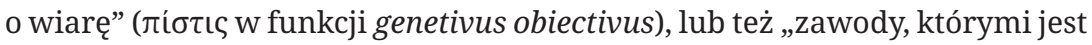

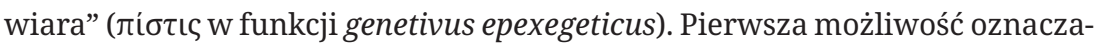
łaby albo dalszą działalność misyjną lub troskę o wiarę Tymoteusza i powierzonych mu chrześcijan, a wówczas wiara byłaby celem do osiągnięcia przez zawodnika-chrześcijanina. Natomiast druga opcja traktuje „rzeczywistość wiary” jako teren zmagań sportowych. Porównując jednak obie propozycje z przedstawionymi dotąd obrazami agonistycznymi, można stwierdzić, iż to druga interpretacja wydaje się być bardziej poprawna. Życie zgodne z wiarą w Chrystusa jest miejscem walki, a nagrodą, która czeka za wygraną, jest życie wieczne (w. 12). Do tego powołany jest każdy chrześcijanin, a tym bardziej biskup, który od momentu wybrania go na pasterza ma w sposób szczególny być wzorem dla powierzonej mu wspólnoty ${ }^{30}$.

29 Por. L. T. Johnson, The First and Second Letters to Timothy. A New Translation with Introduction and Commentary, New York 2001, s. 249-251 (The Anchor Bible, 35A).

30 Por. H. Langkammer, Listy pasterskie. Pierwszy List do Tymoteusza. Drugi List do Tymoteusza. List do Tytusa, Lublin 2006, s. 78 (Biblia Lubelska). 
Natomiast 2 List do Tymoteusza jako ostatnie pismo św. Pawła stanowi niejako jego testament. Na początku rozdziału 2 Apostoł poleca Tymoteuszowi, by ten kontynuował dzieło przekazywania nauki o Chrystusie poprzez przygotowanie kolejnych uczniów, zdolnych do jej głoszenia (por. 2 Tm 2, 2). Co więcej, działalność ucznia ilustruje też trzema obrazami. Pierwszy z nich przywołuje żołnierza, który ma być zaprawiony do trudu i powinien koncentrować się na działalności wojskowej, a nie zajmować się sprawami zwykłego, codziennego życia. Takie same wymagania dotyczą chrześcijanina, aby był on podobającym się Bogu „wojownikiem” (por. 2 Tm 2, 3-4). Trzeci obraz prezentuje z kolei rolnika jako tego, który pierwszy powinien spożywać plony uzyskane dzięki swojej ciężkiej pracy. W ten sposób Paweł wskazuje, że niewątpliwie głosiciel ma prawo do otrzymania zapłaty (por. 2 Tm 2, 6). Natomiast pomiędzy przedstawieniem żołnierza i człowieka pracującego na roli znajduje się obraz sportowy:

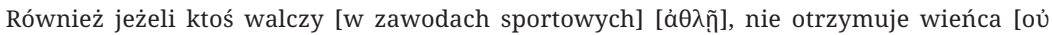

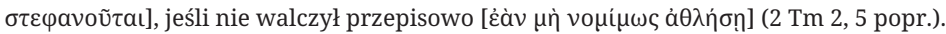

W metaforach sportowych Pawła nagroda uhonorowania wieńcem oznacza najczęściej osiągnięcie zbawienia i przebywania z Bogiem (por. 1 Tes 2, 19-20; 1 Kor 9, 25; 2 Tm 4, 8). Zawodnik, aby ją osiągnąć, musi walczyć zgodnie z przepisami, bo inaczej zostanie zdyskwalifikowany. Jest tu zatem mowa o potrzebie zgodności życia ucznia Chrystusa z wymaganiami Ewangelii ${ }^{31}$, a taka spójność ma jeszcze większe znaczenie, gdy odnosi się do osób zajmujących się głoszeniem Dobrej Nowiny. Trzeba jednak zauważyć, że chociaż myśl o zgodności wiary i codziennego postępowania jest niezmiernie prawdziwa i bardzo istotna, to jednak nie jest ona najważniejsza w tym obrazie. Zdobycie nagrody w sposób przepisowy wymaga pewnej samodyscypliny i dużego wysiłku. W związku z tym konieczność wytrwałości oraz działania pośród trudu i przeciwności jest głównym przesłaniem tego fragmentu, o czym świadczą także sąsiednie wersety ukazujące żołnierza i rolnika ${ }^{32}$.

31 Taki wymóg jest wręcz koniecznością, o czym świadczy użyty w tekście greckim tryb warunkowy eventualis.

32 Por. J. Stępień, Listy do Tesaloniczan i pasterskie, Poznań-Warszawa 1979, s. 119-120 (Pismo Święte Nowego Testamentu, 9). 
Testamentowy charakter omawianego Listu widać jeszcze bardziej w jego ostatnim rozdziale. Paweł najpierw wskazuje, iż ma świadomość zbliżającej się śmierci (por. 2 Tm 4, 6), a następnie dokonuje podsumowania swojego życia:

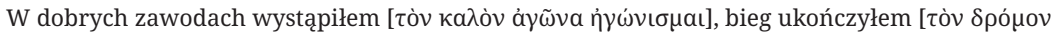
$\tau \varepsilon \tau \varepsilon \dot{\lambda} \varepsilon \kappa \alpha$ ], wiary ustrzegłem. Na ostatek odłożono dla mnie wieniec sprawiedliwości [ò $\tau \tilde{\Upsilon} \varsigma$

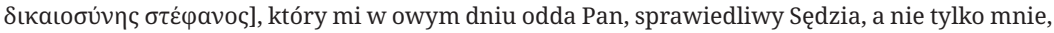
ale i wszystkim, którzy umiłowali pojawienie się Jego (2 Tm 4, 7-8).

Apostoł porównuje tu swoje życie najpierw do zawodów sportowych w ogól-

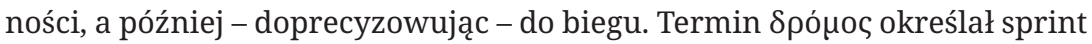
na długość jednego stadionu (192 m), co pokazuje z jednej strony krótkość życia człowieka, a z drugiej podkreśla intensywność wykorzystania tego czasu przez Pawła ${ }^{33}$. Wzmianka o dochowaniu wiary w kontekście zawodów może kojarzyć się z przepisowym sposobem rywalizacji, zgodnym ze złożo-

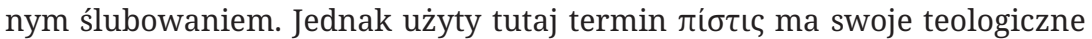
znaczenie, i określa nie tyle wiarę w Jezusa, ale raczej dotrzymanie przez Apostoła wierności powierzonej mu misji głoszenia Ewangelii. Warto zwrócić uwagę, że wszystkie trzy użyte tu czasowniki - „wystąpiłem” (dosł. walczyłem

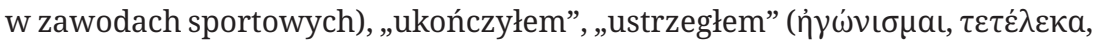

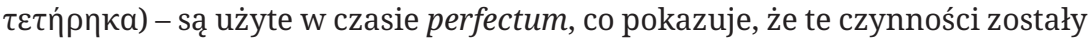
zakończone, ale ich skutki ciągle trwają. Chociaż życie Pawła dobiega już końca, to jednak prowadzona przez niego ewangelizacja zaowocowała tym, że niezliczona ilość ludzi uwierzyła w Jezusa Chrystusa. Wszystko to stanowi niepodważalny dowód, iż zasłużył on na nagrodę, którą tu sam określa jako otrzymanie wieńca sprawiedliwości, a więc wieńca danego sprawiedliwemu właśnie za jego sprawiedliwość. Apostoł Narodów może być niemalże pewien tej nagrody, gdyż arbitrem w tych zawodach jest jedyny zupełnie obiektywny i sprawiedliwy sędzia - Chrystus. Na koniec warto jeszcze wyjaśnić celowe „zaburzenie”, które pojawia się w zaprezentowanym obrazie. W przeciwieństwie do faktycznej rywalizacji sportowej, Paweł nie jest jedynym i wyłącznym zwycięzcą tych zawodów. Współwygrać z nim może każdy, kto swoim życiem udowodni, iż miłuje Jezusa, gdyż właśnie to oznacza wyrażenie „umiłować pojawienie się Jego"34.

33 Por. A. Rambiert, Bieg Pawta z Tarsu..., dz. cyt., s. 61-62, 67-68.

34 Por. L. T. Johnson, The First and Second Letters to Timothy..., dz. cyt., s. 431-432. 


\section{Zakończenie}

W przedstawionych wyżej tekstach widać wyraźnie, że św. Paweł nierzadko wykorzystywał w swoich Listach i nauczaniu obrazy sportowe ${ }^{35}$. Używał przy

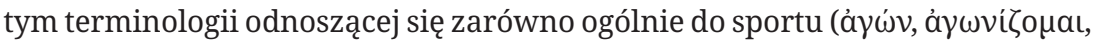
á $\theta \lambda \dot{\varepsilon} \omega$ ), jak też do konkretnych dyscyplin sportowych (biegi: $\tau \rho \dot{\chi} \chi \omega, \delta \rho o ́ \mu о \varsigma$,

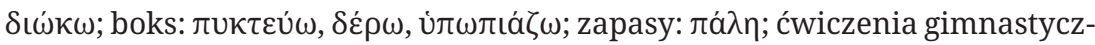

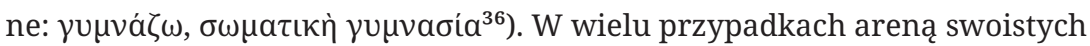
działań sportowych Pawła jest prowadzona przez niego wędrowna działalność ewangelizacyjna, która, jak należy zauważyć, była jego szczególnym, osobistym powołaniem. Uzasadnioną zatem rzeczą jest przeniesienie większości wskazań dotyczących głoszenia Dobrej Nowiny na obszar misji, jaką Bóg wyznacza każdemu chrześcijaninowi.

Na drodze swego życia uczniowie Chrystusa napotykają na niejedną przeciwność i trudność. Muszą zatem wykazać się wytrwałością i dołożyć wszelkich starań, by zachować wierność Chrystusowi i Jego Ewangelii. Jednakże, aby tego dokonać, potrzeba roztropności, a tę można uzyskać dzięki ascezie - ale nie podejmowanej dla niej samej, lecz takiej, która prowadzi do pogłębienia relacji z Bogiem. Wiara jest też rzeczywistością walki duchowej, którą chrześcijanin powinien prowadzić poprzez praktykowanie cnót: sprawiedliwości, pobożności, wiary, miłości, wytrwałości i łagodności, a także poprzez żarliwą modlitwę. Ważnym aspektem jest też trwanie we wspólnocie uczniów Jezusa. Takie wskazania są doskonałą pomocą dla każdego, kto chce zdobyć nagrodę życia wiecznego z Bogiem, a jednocześnie pragnie tego również dla osób spotkanych na swojej drodze.

35 W pozostałych księgach Nowego Testamentu można odnaleźć zaledwie kilka nawiązań do sportu: Dz 13, 25; 20, 24; Hbr 5, 14; 6, 20; 10, 32; 12, 1-4. 11-15 oraz ewentualnie niektóre teksty zawierające motyw wieńca: Jk 1, 12; 1 P 5, 4; Ap 2, 10; 3, 11. Spośród tych fragmentów najbogatszy obraz zawarty jest w Hbr 12, a jego dokładniejsze omówienie można znaleźć w P. Wańczyk, Wpatrzeni w Jezusa. Życie chrześcijan w świetle Listu do Hebrajczyków, Kraków 2015, s. 18-31. 40n.

36 Niektórzy autorzy ponadto dostrzegają w pismach Pawłowych także walki gladiatorów oraz konne ćwiczenia rycerskie i zaliczają je do obrazów sportowych. Por. J. P. Urbański, Język metafor i dyscyplin sportowych..., dz. cyt., s. 272; W. Augustynek, „Arena sportowa” w Listach św. Pawła, „Ruch biblijny i liturgiczny” 6 (1953) nr 1-6, s. 173, https://doi.org/10.21906/rbl.2521. 


\section{Abstrakt}

\section{Przesłanie obrazów sportowych zawartych w Listach św. Pawła}

Św. Paweł w swoich Listach wielokrotnie używa obrazów sportowych, i to zarówno odnoszących się do sportu w ogólności, jak i do jego poszczególnych dyscyplin (biegi, boks, zapasy, ćwiczenia gimnastyczne). Jednak wykorzystanie tematyki sportowej nie jest dla niego celem samym w sobie, lecz ma za zadanie przekazanie adresatom konkretnych wskazówek. Przeprowadzone analizy egzegetyczne pokazują, że Apostoł Narodów porównuje życie swoje i innych chrześcijan do zmagań sportowych. Terenem tych zawodów jest droga wiary w Jezusa, na której pojawiają się liczne trudności i przeciwności. Dlatego sportowiec-chrześcijanin, chcący zdobyć nagrodę życia wiecznego, powinien się cechować m.in. wytrwałością, ascezą, praktykowaniem cnót i modlitwy, a co najważniejsze, jego zadaniem jest staranie się o jak najlepszą relację z Bogiem i wspólnotą wierzących.

Słowa kluczowe: św. Paweł, sport, zawody sportowe, agonistyka

\section{Abstract}

\section{The Message of Athletic Images Contained in St. Paul's Epistles}

In his epistles, St. Paul frequently makes use of athletic imagery, both in relation to sport in general and to specific athletic disciplines (running, boxing, wrestling, gymnastics). However, the use of athletic themes is not an aim in and of itself for St. Paul, but rather it is intended to give specific guidelines to his audience. An exegetic analysis shows that the Apostle to the Nations compares his life and that of other Christians to athletic competitions. The field of these competitions is the way of faith in Jesus in which there are numerous difficulties and obstacles. Hence, the Christian as an athlete who wants to experience eternal life should be persistent, ascetic, practice virtues and prayer, and, most important, his or her task is to have a close relationship with God and the community of believers.

Keywords: St. Paul, sport, athletic competitions, agonistics

\section{References}

Abramowiczówna, Z. (Ed.). (1958). Stownik grecko-polski: Vol. 1: A-A. Państwowe Wydawnictwo Naukowe.

Augustynek, W. (1953). „Arena sportowa” w listach św. Pawła. Ruch Biblijny i Liturgiczny, 6(1-6), 172-174. https:// doi.org/10.21906/rbl.2521

Bańko, M. (2005). Wielki stownik wyrazów obcych PWN (1st ed.). Wydawnictwo Naukowe PWN.

Barth, M. (1974). Ephesians. Translation and commentary on chapters 4-6. Doubleday.

Baslez, M.-F. (2006). Antyczne chrześcijaństwo wobec kultury sportowej świata grecko-rzymskiego. Communio.

Międzynarodowy Przegląd Teologiczny, 26(4), 3-11.

Bednarz, M. (2007). 1-2 List do Tesaloniczan. Edycja Świętego Pawła.

Broneer, O. (1962). The Apostle Paul and the Isthmian Games. The Biblical Archaeologist, 25(1), 2-31. https://doi. org/10.2307/3211017

Fee, G. D. (1987). The First Epistle to the Corinthians. Eerdmans.

Fitzmyer, J. A. (2008). First Corinthians. A new translation with introduction and commentary. Yale University Press. Flis, J. (2011). List do Filipian. Edycja Świętego Pawła.

Hansen, G. W. (2009). The letter to the Philippians. William B. Eerdmans Pub. Co. 
Hawthorne, G. F. (2004). Philippians (revised edition). Nelson Reference \& Electronic.

Johnson, L. T. (2001). The first and second letters to Timothy. A new translation with introduction and commentary. Doubleday.

Kasiłowski, P. (1998). Metafory sportowe w Listach Pawła. In Z. Dziubiński (Ed.), Salezjanie a sport (pp. 34-42). Wydawnictwo Salezjańskie.

Langkammer, H. (Ed.). (2006). Listy pasterskie: Pierwszy List do Tymoteusza, Drugi List do Tymoteusza, List do Tytusa. Wydawnictwo KUL.

Moreau, D. (2006). „Biegnijcie, aby zwyciężyć”. Bieg wytrzymałościowy a życie chrześcijańskie. Communio. Międzynarodowy Przegląd Teologiczny, 26(4), 24-38.

Popowski, R. (1994). Wielki stownik grecko-polski Nowego Testamentu. Wydanie z petna lokalizacja greckich haset, kluczem polsko-greckim oraz indeksem form czasownikowych. Oficyna Wydawnicza Vocatio.

Rambiert, A. (2013). Bieg Pawła z Tarsu, czyli spotkania z grecka agonistyką. Tum Wydawnictwo Wrocławskiej Księgarni Archidiecezjalnej.

Rambiert-Kwaśniewska, A. (2015). ,Walcz w dobrych zawodach o wiarę” (1 Tm 6, 12a). Relektura metaforyki sportowej w listach proto- $i$ deuteropawłowych. TUM Wydawnictwo Wrocławskiej Księgarni Archidiecezjalnej. Stępień, J. (Ed.). (1979). Listy do Tesaloniczan i pasterskie. Wstęp, przekład z oryginału, komentarz. Pallottinum. Urbański, J. P. (2004). Język metafor i dyscyplin sportowych w Tradycji Pawłowej. Bielsko-Żywieckie Studia Teologiczne, 5, 263-278.

Wańczyk, P. (2015). Wpatrzeni w Jezusa. Życie chrześcijan w świetle Listu do Hebrajczyków. Wydawnictwo i-Press. 